\title{
Buying Books for 92 Junior Colleges
}

Thomas R. Barcus is assistant to the chairman of the Carnegie Corporation Advisory Group on Academic Libraries.

URING the years 1925-28 the Carnegie 1 Corporation made a number of exploratory grants for the development of college libraries and in the fall of 1928 it set up an Advisory Group on College Libraries with Dr. William Warner Bishop, librarian of the University of Michigan, as chairman. ${ }^{1}$ A few years later it set up an Advisory Group for Junior College Libraries, also with Dr. Bishop as chairman. Both groups were concerned with book purchases for a selected group of academic libraries.

It was decided at an early date that it would be best to set up a central purchasing office to handle the expenditure of the book funds. A few of the older and larger four-year colleges had well-established order departments and in these instances the grants were expended directly by the colleges and not through the central purchasing office. In the vast majority of cases, however, the placing of orders was handled by the central office. There were thought to be several advantages in this procedure. In the first place, better discounts should be obtainable through centralized purchasing. Individual colleges would be spared much of the keeping of records and correspondence with dealers. Placing the office in Ann Arbor, in the general library of the University of

${ }^{1}$ See the article by Robert M. Lester in this issue of College and Research Libraries, pp. $72-77,83$.
Michigan, meant that the office would have available all the resources of a large university library, its depository catalog, printed catalogs and bibliographies, and all the professional tools ordinarily to be found only in the largest libraries. It would be able to call on the order and reference department staffs, refer questions to the faculty of the Department of Library Science, and would have the active, daily supervision of the chairman of the advisory group.

Many librarians, particularly in the smaller colleges, had had a limited experience in ordering books and could not be expected to have the same contacts with dealers and publishers which would be available to a central office, purchasing on a large scale. Overworked, they would lack the time needed to become familiar with the many dealers and their specialties, with the used book and back numbers market, and would lack the opportunity, afforded by buying the same titles for many colleges, to compare prices and service over a wide field.

Though the office has spent approximately $\$ 1,300,000$ in the past eight years, payments in a single month sometimes amounting to over $\$ 20,000$, there have never been more than two people on the staff: a trained librarian and a secretary, with occasional extra stenographic help. The University of Michigan has generously provided office space, heat and light free of charge, and its librarian, Dr. Bishop, has supervised the operations of 
the office without recompense. This has enabled a very large volume of business to be handled with a surprisingly small overhead, office expenses being paid by the Carnegie Corporation from a separate fund and not deducted from the total available for the purchase of books.

\section{Selection of Titles}

The cardinal principle, rigorously adhered to, has been that the colleges themselves are entirely responsible for the selection of titles. Both the Shaw and Mohrhardt lists were intended to be merely suggestive and no college has been under any obligation to buy a single title in either list. The only stipulation has been that purchases should be largely for undergraduate use. There has also been a stipulation that not more than three copies of any one title would be purchased. This was intended to prevent the money being spent largely for the purchase of many duplicate copies of a few required texts. It has been the experience of the advisory group that an institution can usually provide from its own funds the needed supply of texts but that it is far more difficult to secure funds for journals, reference sets and recreational reading.

We have never refused to buy any title ordered by a librarian and have purchased everything from The Tale of Peter Rabbit to the Oxford English Dictionary. In a few cases involving subscription sets of doubtful value we have called the librarian's attention to an unfavorable review in such a source as the Subscription Books Bulletin. But even in these cases, if the librarian still wished to have the set, despite the unfavorable review, it was ordered for the library. Many valuable reference sets, such as the standard dictionaries and encyclopedias, the Mythology of All Races, the Cambridge histories, Smithsonian Scientific Series, Dictionary of American Biography, Dictionary of National Biography, and Encyclopedia of the Social Sciences have been added to libraries which would otherwise have been unable to afford them. Many periodical sets have been filled in and many copies of excellent titles in fiction, poetry, drama, travel, biography, history and current affairs have been supplied to the great enrichment of the libraries receiving them; all this, too, during depression years when most library budgets were being curtailed.

Periodical subscriptions have usually not been taken since it was found that the tendency was to let them lapse after the expiration of the grants and it was felt that a run of only three years would be of little value. We have, however, always been willing to pay for binding them.

A certain number of maps, scores, phonograph records, and pictures have been purchased as being reasonably within the terms of the grants. We have, however, had to decline to purchase such objects as mineralogical specimens and slides which seemed a little too remote from library purposes.

\section{Low Postal Rate a Help}

All the grants have been made available in three equal annual installments in order not to place too great a burden on the library's catalogers. Carriage charges are paid by the colleges, in order to make the full amount of the grant available for the purchase of books. The present postal rate of a cent and a half a pound has, of course, been a tremendous help.

It may be of some interest briefly to outline the routine followed with a typical order. It soon became apparent that the best results would be obtained by supply- 
ing the colleges with uniform order blanks and instructions for using them. Our present forms have a space for the name and location of the college, number and date of the order, and call for author, title, publisher, list price, and number of copies wanted for each title listed. They are filled out by the colleges in triplicate, one copy being kept by the college and the other two being forwarded to the central purchasing office.

In order to avoid a great volume of small orders we have requested that ordinarily not less than ten titles be ordered at one time, and that the different categories of books be listed on separate sheets. The categories include current American books, current British books, out-of-print titles, books printed on the continent, periodical sets, and orders for items or sets costing over $\$ 25$.

Every order received gets individual attention but a division of titles along the lines just indicated makes the work of placing it a far easier and quicker task.

\section{Buy from 80 Firms}

Since purchases on the junior college grants began in the fall of 1937 we have bought books from some eighty different firms but the majority of orders have gone to four or five big dealers in New York and Chicago. Only by centralizing purchases in this way has it been possible to handle a large volume of business with so small a staff. Again, since we were able to offer a large and continuing volume of business, it has been possible for the dealers to give very favorable discounts, more favorable than any but the largest libraries could ordinarily obtain.

At least two of the firms patronized are generally able to supply out-of-stock books priced to meet the special offers made by other dealers. In the case of a rare item, the work can nearly always be obtained from its owner by one of our regular dealers at no increase in price and without the trouble of opening a new account. This renders largely unnecessary the patronizing of a great number of dealers, though of course we check the catalogs of many firms, maintain a card file of expensive items offered by them at special prices, and place trial orders from time to time in order to be sure that we are obtaining for the colleges as good discounts and service as possible.

We will buy from small local dealers or from individuals when the material is hard to obtain elsewhere or when exceptional prices have been offered the colleges but we usually stipulate that purchases should amount to at least $\$ 25$ in order to keep our list of dealers within reasonable bounds.

When an order has been properly grouped by a college, it is usually a simple matter to determine which of our dealers will probably give the best prices and the most satisfactory service on a given list of titles. We maintain a card file covering the varying rates of discount, whether postage is paid, the size of the dealer's stock, his success in supplying out-of-print titles, and similar items likely to be useful in arriving at a decision.

Orders are nearly always forwarded to the dealers the day they are received by the central office. At the same time a form postcard is sent the college informing it of the disposition of its order. An entry is also made in a notebook, showing the number and date of the order, with what dealer or dealers it was placed, its estimated cost, and the balance remaining to the college. The third copy of the order (one having been retained by the college 
and one sent to the dealer) is then filed in the central office.

\section{Handling Invoices}

Dealers are requested to send two copies of each invoice to the colleges and one copy to the central office. When received, our copy of the invoice is checked item by item against the original order and then entered in a ledger, each entry indicating the dealer, the date of the invoice, and the amount. When the college forwards one of its copies of the invoice, marked to indicate that the books have been received, our entry is checked to show that the invoice has been approved for payment.

We now have two copies of each invoice, our original copy and the copy approved by the college. They are stapled together and are assembled once each month for payment. I shall not describe this process in detail. Suffice it to say that a sheet is made out in triplicate for each dealer, showing the amounts due from each college. One copy is kept in the central purchasing office, one is for the files of the corporation itself, and the third is sent to the dealer, accompanied by a check from the corporation for the total amount due and by a list of the invoices which the check covers.

We maintain an account book showing each college's original grant and in it is entered each month the invoices paid from the grant. The book is balanced monthly and it is possible to tell at a glance just how much of each grant has been spent and how much remains. The same list of invoices is sent immediately after the monthly payment to each college. In this way the colleges have available at all times every figure in the possession of the central office which relates to their grants.

A device has been adopted which greatly simplifies the closing out of the grants. The colleges are asked to refrain from spending approximately the last two hundred dollars of their allotment and are sent this amount in cash, after they have agreed to be responsible for any small bills which may straggle in after the grants have been closed. At the same time our records for the college are checked for the last time with those maintained by the corporation itself and the dealers are notified. They are usually willing to give a college the same discount on the final $\$ 200$ whether it is spent directly or through the central purchasing office.

\section{Librarians Need Training in Business Methods}

It has been a very interesting experience-buying books for 92 junior colleges and also for the 29 teachers colleges which received grants totaling \$180,000 last December. Among other impressions gathered is the feeling that there is considerable need in our library schools for a more extended training in order work and in elementary business methods. Certainly in my own library school experience little time and attention were given to order work as compared with the long and detailed courses devoted to book selection, cataloging, and classification. To make matters worse, one who wishes to supplement a too-brief formal training in the subject, will find very little in print and particularly little of recent date. It is necessary to fall back upon that best but most expensive of teachers, experience, supplemented by conversations with dealers and with other librarians.

The majority of the two hundred and fifteen librarians for whom we have purchased books in the past eight years have been business-like in their dealings with us 
and with the dealers. We have, however, been surprised at the number of those who did not know with any accuracy what their current balance was, though they had in their possession every figure which was available to us. Overcharges or duplicate billings are frequently not caught. Credit slips seem to be a mystery to some. A surprising number seem not to read the indispensable Subscription Books Bulletin; a few try to get along without the United States Catalog.

There have, however, been few such instances and they become increasingly rare as the spending of the grants draws to a close. The great majority have continued at all times to do an excellent job of ordering on their grants. We have asked the librarians to write us about special offers and new dealers of whom they may learn and we have received much valuable information in this way.

Coming finally to the results of the grants made by the Carnegie Corporation, I shall not attempt to describe them in any detail since Mr. Robert M. Lester, secretary of the corporation, has covered the subject with authority. ${ }^{2}$

It is enough to say that many thousands of books have been added to the college libraries of the country, nearly all of them worthy additions. As an experiment we have taken some of the copies of the Mohrhardt list originally checked by the junior colleges to show their holdings and checked them again to show titles purchased since the grants were made. It has been pleasant to note gaps filled in and weaknesses made good. Thousands of books of equal caliber, not represented among the 5500 titles in the Mohrhardt list or published since its appearance, have of course also been purchased.

$$
2 \text { Op. cit. }
$$

\section{Estimated Savings on Purchases}

Exact figures are, in the nature of things, out of the question but it is possible that the colleges have obtained from Io per cent to I 5 per cent more for their money than they would have obtained spending it individually. We have at different times estimated the average discount as being from 23 per cent to $27 \frac{1}{2}$ per cent. Perhaps 25 per cent is as good a figure as any. This figure includes a very large number of technical books on which low or no discounts are available, and very many out-of-print titles which may cost more than the list price.

I think that we have saved the colleges additional sums by writing for quotations on expensive items, comparing prices constantly, and in general keeping in closer touch with the book market than most busy college librarians find possible. They have saved time and postage through being able to send all orders and invoices to one address, and a considerable burden of correspondence has been taken off their hands. They have been invited to write the central office at any time for advice and information and we have always tried to refer their questions to the best available sources.

We have made particular efforts to secure for the colleges exactly the titles desired, regardless of their scarcity and have usually been successful in securing what was desired, though in some instances it has required prolonged searching.

\section{Other Results of Grants}

This influx of new books has, of course, stimulated reading and has had its effects on circulation figures. Many junior colleges report very large increases. Many report a new attitude toward the library on the part of the administration, faculty 
and students. At least one junior college has been inspired to undertake a very interesting survey of the reading habits and library attitudes of its students, as affected by the Carnegie grant.

Some report that the grant has provided the impetus needed to secure a new library building, new furniture and equipment, an addition to the staff, or an increase in the library's appropriation. Others describe additional gifts from other sources, gifts which might not have come without the publicity attending the Carnegie grant.

One librarian eloquently summed up the matter by writing:

The grant seems to be the force for bringing about many of the things we have long planned for. To see the library grow in usefulness, to see a renewed interest by the faculty as a whole, and to feel that we can begin to approach the type of service that we should give as a junior college library is very gratifying.

The grants should in the long run prove of benefit to all junior college libraries. The standards prepared by the advisory group, the List of Books for Junior College Libraries, the numerous articles and statistical studies initiated by the group should be of service. An increased demand for trained librarians in the junior college field can be attributed in part to the work of the advisory group. Most important, executive officers and governing boards have been stimulated as never before to think about library problems and are coming to realize the need for more adequate appropriations.

To quote Dr. Eells:

The primary object of the Corporation, after all, was not so much to aid particular junior colleges as to stimulate all junior colleges to improve their library collections and service. Within a short time the grants will all have been expended, but the influence of the entire study will far outlast this limited period. All of the junior colleges in the country, whether included in the smaller number which actually received grants or not, can and will profit greatly from the other phases of the study, the book list, the standards, the statistical information, and most important of all in many cases, the realization on the part of administrators of the fundamental importance of the library in any real program of college education. Perhaps in the long run general junior college stimulation and development of library consciousness will be the most important and permanent outcome of the three years of work of the Carnegie Corporation's Advisory Group on Junior College Libraries. ${ }^{3}$

${ }^{3}$ Junior College Journal, 6:17, January, 1937.

\section{Carnegie Corporation Aid to College Libraries}

\section{(Continued from page 77)}

academic "Colonel Andersons" make them accessible? These are questions that give us pause.

The trustees and officers of the corporation are certainly not under the delusion that the average undergraduate-if there be such-is panting for knowledge and yearning for books to the detriment of his health and the despair of his professors. But it is believed that as the years go by, the usefulness of books will become more and more impressed on the consciousness of the academic community, and that the wide-awake professors, librarians, and presidents-and there are many of this kind who drive students to bookswill so adapt college teaching that students will be eager to draw upon what President Wilkins has termed, "the transforming riches of the library." 